\title{
ARCHITECTURE TOOLS MEASURE THE LEVELS OF SALT AND PH OF SEAWATER USING A FUZZY LOGIC-BASED ANDROID
}

\author{
Achmad Ubaidillah, Diana Rahmawati, Rocky Aiman
}

\begin{abstract}
The sea has many potentials to be utilized based on the ecological aspects of coastal area. Almost in the coastal areas and islands in Madura are experiencing difficulties in utilizing marine resources. Salinity changes influenced by water osmotic pressure whereas biota living in salt water should be able to adjust the osmotic pressure from its environment. The changes in $\mathrm{pH}$ have an effect on the survival of marine organisms as not all saltwater creatures survive with the change of it. From these problems a system of "Designing Measure of Salt Measure and Sea Water pH Using Fuzzy Logic Based Android" is made. Where measuring system is made to prioritize the level of accuracy of changes in salinity and $\mathrm{pH}$ value of sea water. So that people could exploit the sea potential based on the condition of the sea water. The reading of sea water condition changes using salinity sensors, $\mathrm{pH}$ sensors, and MCU nodes as communication with android devices. Input from the sensor can be sent to the web server and received by android and then processed by fuzzy logic method to get the maximum output. The system can work according to what is expected during 5 days of testing in different locations. The success of this system is $\mathbf{9 7 . 3 \%}$ with a $2.07 \%$ failure rate.
\end{abstract}

Index Terms-Sea water, Fuzzy Logic, Internet of Things, Salinity Sensor, pH Sensor.

\section{INTRODUCTION}

$\mathrm{T}_{1}$ HE coastal and sea area has a very high potential to be develope by coastal communities, but the resourcesof marine and fisheries in coastal areas and the sea while it's still a lot that has not been maintained in accordance with the characteristics of the territory. So still haven't been able to improve the economy of coastal communities to the maximum.

With the oceans which is $70 \%$ of the total area of the Malay Archipelago, then the sea holds a great potential to be utilized, among other things, the cultivation pond salt is sea grass and mangrove [1]. So by making use of the potential of the coastal area as well as mainly in the cultivation of seaweed, has the potential to improve the economy of coastal communities.

Achmad Ubaidillah, Diana Rahmawati, Rocky Aiman is with the Electrical Engineering Departement of Universitas Madura, Indonesia (email: ca_achmed@yahoo.com)

Diana Rahmawati is with the Electrical Engineering Departement of Universitas Madura, Indonesia (email: diana_rahmawti@yahoo.com)

Rocky Aiman is with the Electrical Engineering Departement of Universitas Madura, Indonesia (email: rockyaiman1@gmail.com)
In this study, there is a process that is used to check the conditions of salinity and $\mathrm{pH}$ of seawater. A process that is done is the sensor will detect the condition of the sea water. Sensor readings against the conditions of the sea water is sent to the web server received the android and processed using fuzzy logic method to know the $\mathrm{pH}$ and salinity in sea water accurately. Android GUI will display the value of the output of the sensors and fuzzy logic. To transmit data from sensors using a wifi module which is connected with the internet.

It has been a lot of research as well as the article that discusses about salt levels Sensor, pHdan fuzzy logic. The following source reference that supports this research:

In a study titled "Making gauge salinity and turbidity of water using sensor electrodes and LDR". Characteristics of copper electrode as sensor salinity i.e. the higher the levels of salinity samples were measured, then the output voltage sensor electrodes are also getting bigger. Characteristics of turbidity sensors as LDR i.e. the higher the water turbidity levels measured, then the output voltage sensors getting smaller. ${ }^{[2]}$

The study, entitled "design and implementation of measuring instrument for the determination of water quality-based method of Sugeno Fuzzy logic". 8 points from the test site, the tool is able to receive and display the data properly. It can be seen from the table of results of testing, where the minimum $\mathrm{pH}$ value obtained is the maximum value and 7.03 is 8.21 . Minimum turbidity value for the maximum value of 589.7 was and is 2751.5. ${ }^{[3]}$

The study, entitled "architecture of water salinity levels monitoring system using wireless sensor system (wss)". Digital data is then sent using the microcontroller serial communications to a computer. Measurement results data is stored in a database and sent to the Control Terminal Unit (CTU) using Wi-Fi networks. ${ }^{[5]}$

Therefore need for a tool that can mengefisiensikan the sea water gauge so that the results in the get more accurate and can be used in real time. The purpose of this tool is to measure the height of low salinity and $\mathrm{pH}$ on seawater for coastal areas eligibility berdsarkan ecological aspects. Where the tool here to work automatically. $\mathrm{PH}$ and salinity sensors are as low salinity and high measuring $\mathrm{pH}$ in the sea water. The value of Salinity and $\mathrm{pH}$ on tools processed with fuzzy logic method to get the value of the output that is more accurate and is featured on the android GUI. The 
success of this system of $97.93 \%$ failure rate with $2.07 \%$.

\section{Material And Methodes}

\section{A. Fuzzy Logic}

Fuzzy logic can apply fuzzy method in the system to give a decision on the system and made the output system according input data from the sensor. The results of the tests will be compared from fuzzy logic decision system results with results mathematically.

- Variable Salinity Sensor Membership Function

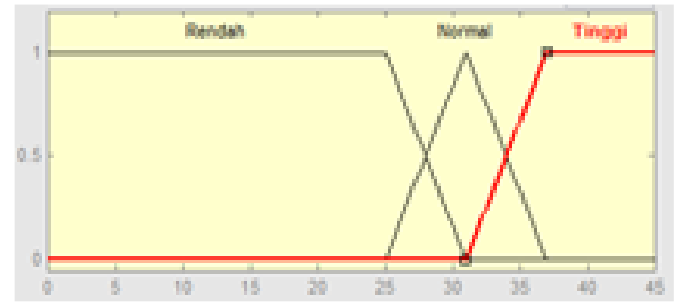

Figure 1. Membership Function Input Salinity

$$
\begin{aligned}
\mu[\mathrm{x}] \text { Low } & =\left\{\begin{array}{cc}
1 & x \leq 25 \\
\frac{a 1-x}{a 1-25} ; & 25 \leq x \leq 31 \\
0 & x \geq 31
\end{array}\right. \\
\mu[\mathrm{x}] \text { Normal } & =\left\{\begin{array}{cc}
0 & x>31 \\
\frac{x-25}{a 1-25} ; & 25 \leq x \leq 31 \\
\frac{a 7-x}{a 7-a 1} & 31 \leq x \leq 37
\end{array}\right. \\
\mu[\mathrm{x}] \text { High } & =\left\{\begin{array}{cc}
0 & x \leq 31 \\
\frac{x-a 1}{a 7-a 1} ; & 31 \leq x \leq 37 \\
1 & x>37
\end{array}\right.
\end{aligned}
$$

- $\mathrm{pH}$ Sensor Variable Membership Function

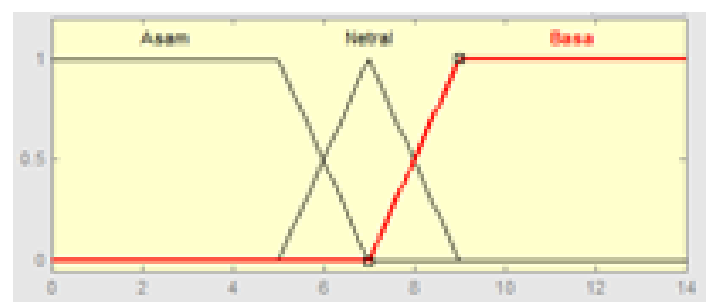

Figure 2. Membership Function Inputs $\mathrm{pH}$

$$
\begin{aligned}
\mu[\mathrm{x}] \text { Acid } & =\left\{\begin{array}{cc}
1 & x \leq 5 \\
\frac{7-x}{7-5} ; & 5 \leq x \leq 7 \\
0 & x \geq 7
\end{array}\right. \\
\mu[\mathrm{x}] \text { Neutral } & =\left\{\begin{array}{cc}
0 & x>7 \\
\frac{x-5}{7-5} ; & 5 \leq x \leq 7 \\
\frac{9-x}{9-7} & 7 \leq x \leq 9
\end{array}\right. \\
\mu[\mathrm{x}] \text { Base } & =\left\{\begin{array}{cc}
0 & x \leq 7 \\
\frac{x-7}{9-7} ; & 7 \leq x \leq 9 \\
1 & x>9
\end{array}\right.
\end{aligned}
$$

\begin{tabular}{|c|c|c|c|c|}
\hline & \multicolumn{3}{|c|}{ Salinitas } \\
\hline & & Low & Normal & High \\
\hline \multirow{3}{*}{$\mathrm{pH}$} & Acid & $\mathrm{Bu}=25$ & $\mathrm{~N}=28$ & $\mathrm{~N}=28$ \\
\hline & Neutral & $\mathrm{N}=28$ & $\mathrm{Ba}=34$ & $\mathrm{Ba}=34$ \\
\hline & Base & $\mathrm{N}=28$ & $\mathrm{~N}=28$ & $\mathrm{Bu}=25$ \\
\hline \multicolumn{5}{|c|}{ Description: } \\
\hline & & $\mathrm{Ba}$ & Good & \\
\hline & & & Normal & \\
\hline
\end{tabular}

- Variable Membership Function Outputs The State

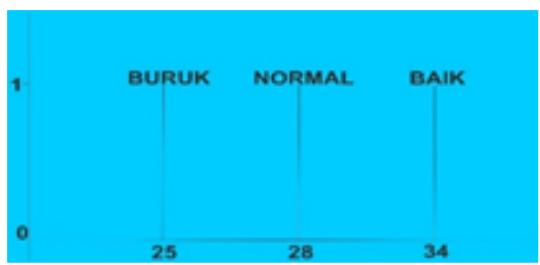

Fig. 3. Membership Function Outputs The State Of Sea Water of Sea Water

TABLE I

FuZZY RULE OF TABLE 1 (RULE BASE)

- The Rules (Rule)

If salinity $=30.59 \mathrm{ppt}$ and $\mathrm{pH}=7.07$

On the above issues for fuzzy membership functions are used in this research are as follows:

1. Find the value of fuzzifikasi, variable normal membership:

- Salinity $=30.59$ included in low and normal membership

$$
\begin{aligned}
\mu \text { low }[\mathrm{x}] & =\frac{31-x}{31-25}=\frac{31-30.59}{31-25}=\frac{0.41}{6} \\
& =0.06 \\
\mu \text { normal }[\mathrm{x}] & =\frac{x-25}{31-25}=\frac{30.59-25}{31-25}=\frac{5.59}{6} \\
& =0.93
\end{aligned}
$$

- $\mathrm{pH}=7.07$ including membership in neutral and alkaline

$$
\begin{aligned}
\mu \text { neutral }[\mathrm{x}] & =\frac{9-x}{9-7}=\frac{9-7.07}{9-7}=\frac{1.93}{2} \\
& =0.96 \\
\mu \text { base }[\mathrm{x}] & =\frac{x-7}{9-7}=\frac{7.07-7}{9-7}=\frac{0.07}{2} \\
& =0.03
\end{aligned}
$$

2. Looking for value of fuzzy rules (rules base) as follows:

Description:

$\alpha_{i}: \quad \alpha$ the predicate on the rule to the $-i$

$\mathrm{z}_{i}: \quad$ output on rules to $a-i$

- [R1] IF low salinity AND pH neutral THEN normal output $=28$

$$
\begin{aligned}
\alpha-\text { predicate } 1 & =\operatorname{Min}(\mu \text { low }[\mathrm{x}], \mu \text { neutral }[\mathrm{x}] \\
& =\operatorname{Min}(0.06,0.96) \\
& =0.06 \\
\mathrm{z} 1 & =28(\text { Normal })
\end{aligned}
$$

- [R2] IF normal salinity AND pH base THEN normal output $=28$

$$
\begin{aligned}
\alpha-\text { predicate } 2 & =\operatorname{Min}(\mu \text { normal }[\mathrm{x}], \mu \text { base }[\mathrm{x}]) \\
& =\operatorname{Min}(0.93,0.03) \\
& =0.03 \\
\mathrm{z} 2 & =28(\text { Normal })
\end{aligned}
$$

3. Looking for the value of the defuzzyfikasi method using the median value for getting the sugeno average weighted by the following formula:

Description:

$$
\begin{aligned}
\mathrm{Z} & : \text { average weighted } \\
\alpha_{i} & : \quad \alpha \text { the predicate on the rule to the }-i \\
\mathrm{Z}_{i} & : \quad \text { output on rules to } a-i \\
\mathbf{Z} & =\frac{(a 1 * z 1)+(\alpha 2 * z 2)}{a 1+a 2} \\
& =\frac{(0.06 * 28)+(0.03 * 28)}{0.086+0.03} \\
& =\frac{1.68+0.84}{0.09}=\frac{2.52}{0.09} \\
& =28
\end{aligned}
$$


So the State of the sea water with salinity $=30.59$ ppt and $\mathrm{pH}=7.07$ is normal $=28^{[11]}$

\section{B. pH Sensor}

$\mathrm{pH}$ is the degree of acidity that is used to determine acidity or basicity by an aqueous solution. It is defined as the kologaritma activity of hydrogen ions $(\mathrm{H}+)$ are dissolved. Hydrogen ion activity coefficient cannot be measured experimentally, so that its value is based on theoretical calculations. He is both relative to a set of standard solutions whose $\mathrm{pH}$ is determined on the basis of an international agreement. When $\mathrm{pH}<7$ the solution is acidic, $\mathrm{pH}>7$ aqueous solution is alkaline. In a neutral solution $\mathrm{pH}=7^{[2]}$.

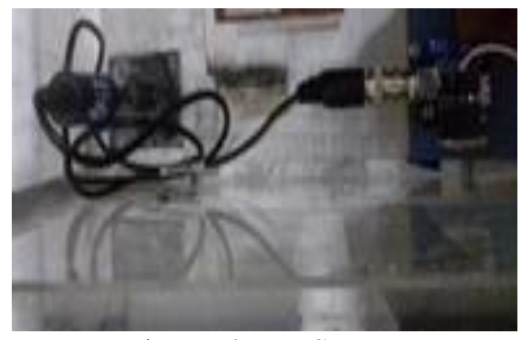

Figure 4. pH Sensor

\section{Sensor Salt Levels}

The sensors Conductivity/TDS/Salt Levels have a compact design. Probe sensors are made of sticks stainless spaces function as the recipient of the data of the material tested. These sensors can be directly connected with pin analog arduino or other microcontroller, analog pin without having to wear an extra amplifier module. ${ }^{[10]}$

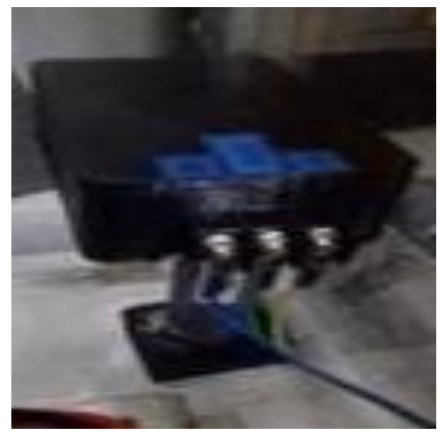

Figure 5. Sensor Salt Levels

\section{Levels of Salt}

Seawater is water from a sea or ocean. Sea water has salt levels on average $3.5 \%$. This means that in 1 liter $(1000 \mathrm{~mL})$ sea water there is 35 grams of salt (mostly, but not entirely, salt $/ \mathrm{NaCl}$ ). While most of the world's sea water contains about $3.5 \%$ salt, seawater also vary the content of salts. The most tasteless is East of the Gulf of Finland and Gulf of Bothnia in the North, both of which are part of the Baltic Sea. The most salty is in the Red Sea, where high temperatures and limited circulation makes high evaporation and little input of water from rivers. ${ }^{[12]}$

On the design of the final task, there are several stages in order to make planning as expected. The following rancengan the system in the form of block diagrams.

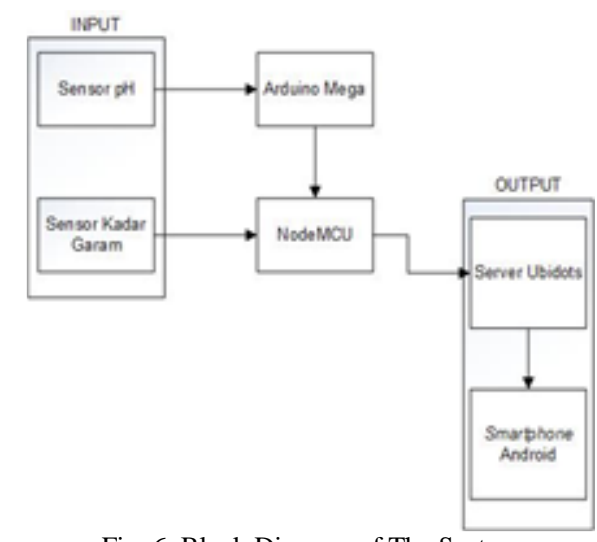

Fig. 6. Block Diagram of The System

From Figure 6. Block diagram of this system describes the relationship of each device. PH sensor as the value msukan for the arduino mega is then dikrim to nodeMCU while the salinity sensor as input to the nodeMCU value. The value of the inputs from the sensors is sent to a web server that is connected to the internet and there is an application on smart phones as the information about the feasibility of sea water by using the specified method.

The design of the software include the design of the system and the design of gui (graphical user interface).

1. Flowchart Sistem

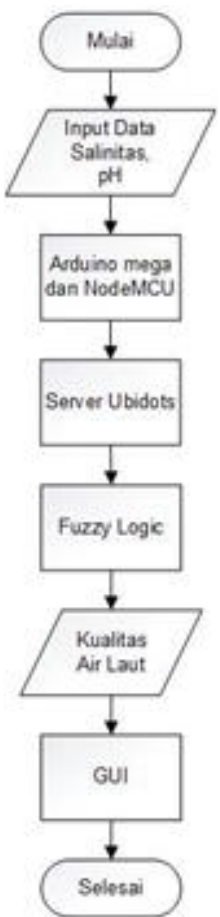

Fig. 7. Flowchart System

In Figure 7. Explain briefly about the workflow of the system to be tested. Salinity sensors and sensors to detect the ph of sea water at the moment is detected by the sensor then the arduino and nodemcu will send data to the server ubidots which are connected to the internet. The data from the server ubidots received by android and analysis by using fuzzy logic method to determine the feasibility of sea water including categories not suitable, appropriate, and very appropriate. The application contained on the smart phone as gui (graphical user interface) to display the results of the 
output values of the sensors and fuzzy logic.

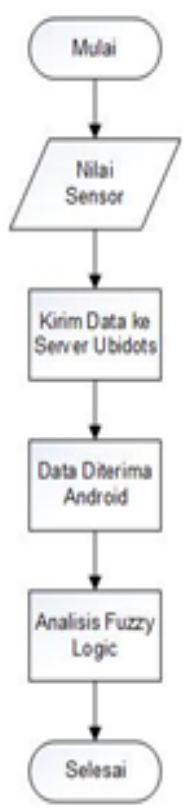

Fig.8. Process Flow Fuzzy Logic

\section{Fuzzy Logic Processing Flowchart}

From Figure 8. the explanation is briefly Groove processing of fuzzy logic. The process of fuzzy logic will be applied to this system. Fuzzy logic used to get an accurate value of the sensor. The sensor will detect the sea water then the value of the data from the sensors will be sent to the server ubidots and accepted by android. The android data received is processed with the method of fuzzy logic including fuzzyfikasi megubah input value into the value of the variable to get the value of the firm, change the value of the input fuzzy inference into fuzzy output by the rules - rules that are specified and defuzzyfikasi change outputfuzzy of the rules - rules that are determined to get the value of the firm. From the results of the sensors and calculation of fuzzy logic is shown to the android GUI.

3. Design of GUI (Graphical User Interface)

Graphical User Interface (GUI) as a display when monitor system. In this study the author uses GUI mobile for android devices. To make the android GUI applications using android mobile studio. On android applications there are a few parts, the first is the opening, the second display is the display of the readings of the sensors in the visualize the look of the sensors and graph the value after the connect. Following

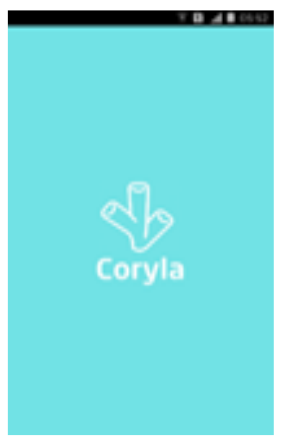

(a)

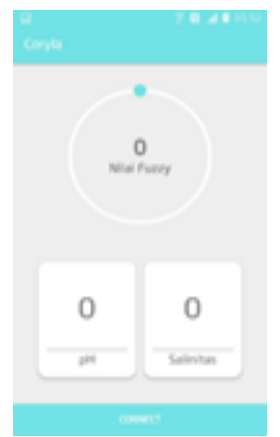

(b)
Fig. 9. (a) The Display of The Splash Screen (b) Display The Android Gui is the display of android applications.

\section{RESULT AND DISCUSSION}

The results of previous research and researchers are as follows:

In a study titled "Making gauge salinity and turbidity of water using sensor electrodes and LDR". The research results obtained by dip sensor into the bottle containing water. Then do the identification data of the salt levels in there panambahan meliputipengaruh airterhadap danpengaruh salinity sensor output voltage variation of turbidity against tegangankeluaran LDR and in view to the LCD. ${ }^{[2]}$

The study, entitled "design and implementation of measuring instrument for the determination of water quality-based method of Sugeno Fuzzy logic". The results of testing conducted with dip sensor into the water in a bottle that already contains the water of the River, and then wait for up to 1 or 2 minutes to get the values of $\mathrm{pH}$ and turbidity. Then the results will be displayed to the LCD. ${ }^{[3]}$

The study, entitled "architecture of water salinity levels monitoring system using wireless sensor system (wss)". The results of research using the conductivity sensor and sensor results stored in the database. Then the result of the sensor will be on show to a desktop application using delphi as a GUI. ${ }^{[5]}$

Difference research researchers from previous research that is. Using sensors, sensor $\mathrm{pH}$ levels of salt and the sensor readings that are used successfully in accordance with the location in the test. Results in produce sensors is sent to a web server using the internet of things later in the show to a smart phone with android GUI.

\section{Testing of The $\mathrm{pH}$ Sensor}

$\mathrm{pH}$ sensor used on this tool to measure the State of the $\mathrm{pH}$ of sea water will be on the test. Testing $\mathrm{pH}$ sensor calibration done by using digital $\mathrm{pH}$ meter and buffer $\mathrm{pH} 6.86$ powder $250 \mathrm{ml}$.

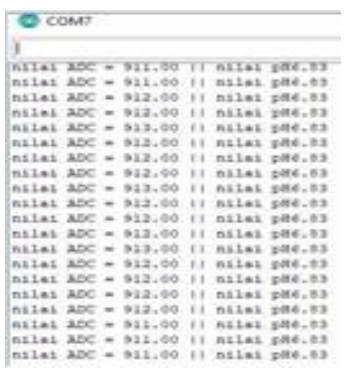

(a)

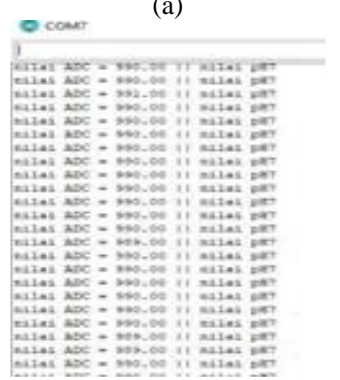

(c)

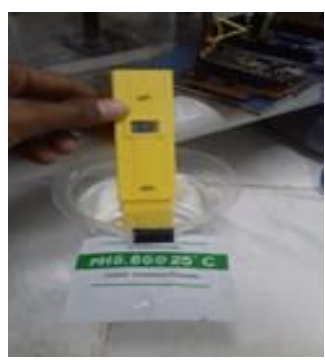

(b)

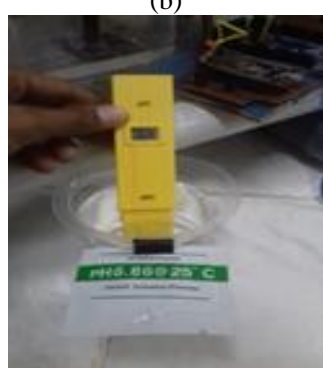

(d)
Fig. 10. (a) the results of the value of $A D C=912,000=p H$ Sensor and the value of 6.83. (b) the results of the Digital $\mathrm{pH}$ Meter $=6.86$. (c) the result is the value of $\mathrm{ADC}=990,000$ and the value of Sensor $\mathrm{pH}=7$. (d) the results of the Digital $\mathrm{pH}$ Meter $=6.86$ 
In figure (a) is the result of the first test with the result value of the $\mathrm{ADC}=912,000=\mathrm{pH}$ sensors, the value of 6.83 and compared with $\mathrm{pH}$ meter with result $=$ 6.86. In figure (c) is the result of the second test with the result value of the ADC sensor value $=990,000, \mathrm{pH}=7$ and compared with $\mathrm{pH}$ meter with result $=6.86$. From the results of sensor $\mathrm{pH}$ the lower hydrogen ions in water value of the $\mathrm{ADC}$ and the resulting low $\mathrm{pH}$ value and vice versa. From the results of sensor and meter tool has an eror align $=0.03-$ and 0.14 .

2. Testing of The Sensor Salt Levels

Sensor salt levels used in this tool to measure the State of the salinity of sea water will be on the test. Salt levels sensor testing is done by means of calibration using digital tds meter-3 and powder salt 1-2 tea spoons.

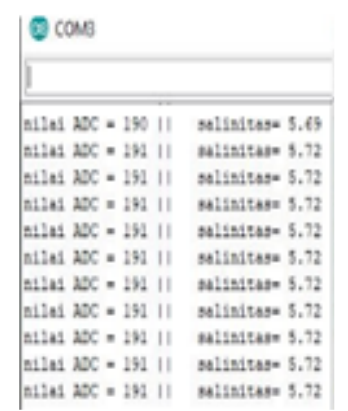

(a)

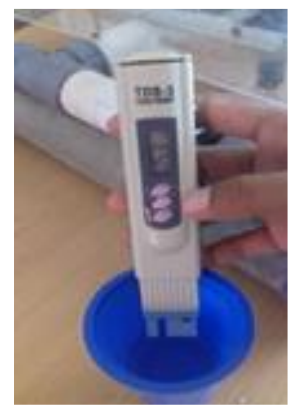

(b)

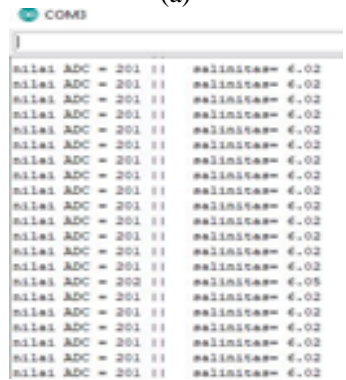

(c)

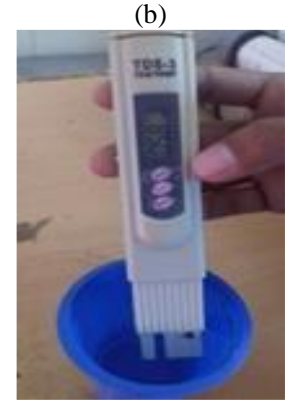

(d)
Fig. 11. (a) the results of the value of $A D C=191$ and the Sensor value levels of salt $=5.72$. (b) results from Digital tds Meter- $3=5.3$

(c) the result is the value of $\mathrm{ADC}=201$ and value levels of salt $=$ 6.02. (d) the results of the Digital tds Meter-3 $=5.8$

In figure (a) is the result of the first test with the result value of the $\mathrm{ADC}=191$ and the Sensor value $=$ 5.72 salt levels and compared with digital tds meter-3 with result $=5.3$. In figure (c) is the result of the second test with the result value of the $\mathrm{ADC}=201$ and value levels of salt $=6.02$ and compared with digital tds meter- 3 with result $=5.8$. From the results of sensor the lower levels of salt the salt levels in measuring the value of ADC and low salt levels and vice versa. From the results of sensor and meter tool has an eror $=0.42$ averages - and 0.22 .

3. Testing of The Measuring Instrument

The purpose of testing this measurement tool to know the State of sea water in order to harness the potential that existed at the location of the coastal area with the use of fuzzy logic in decision making to be output in accordance with input from sensors and this tool android-based connected with internet to access data from the smart phone application.

From the results of testing on juganyar village, bangkalan there results during testing at that location the salinity and $\mathrm{pH}$ of each time to time tested experience changes that are not far away. To display the GUI results shows that the reading of sensors and fuzzy logic controller output value corresponding to the calculation manually. The first location of the coastal hamlet of junganyar, bangkalan.

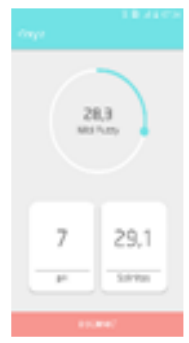

(a)

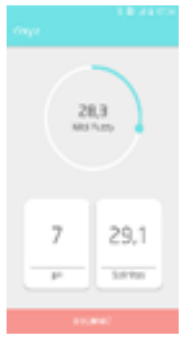

(b)

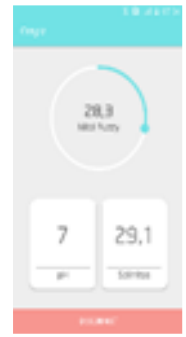

(c)

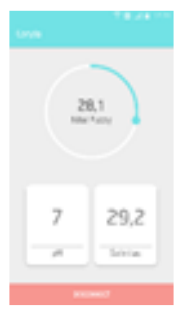

(d)

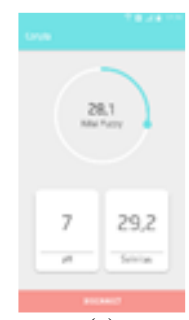

(e)
The Result of The Testing ViLlage Location JuganyaR

\begin{tabular}{cccccc}
\hline \hline No & Time & $\begin{array}{c}\text { Salinity } \\
\text { Sensor } \\
\text { Readings } \\
\text { (ppt) }\end{array}$ & $\begin{array}{c}\text { Ph } \\
\text { Sensor } \\
\text { Readings }\end{array}$ & $\begin{array}{c}\text { The } \\
\text { Value Of } \\
\text { Fuzzy } \\
\text { Logic }\end{array}$ & $\begin{array}{c}\text { The } \\
\text { Condition }\end{array}$ \\
1 & 11.00 & 29.1 & 7 & 28.3 & Success \\
2 & 11.15 & 29.1 & 7 & 28.3 & Success \\
3 & 11.30 & 29.1 & 7 & 28.3 & Success \\
4 & 11.45 & 29.2 & 7 & 28.1 & Success \\
5 & 12.00 & 29.2 & 7 & 28.1 & success \\
\hline \hline
\end{tabular}

From testing all components of hardware and software that the tool can work in accordance with what you want. The result of the detection of the sensor against the sea water in the appropriate test location that has a median error of measurement - averaged $2.07 \%$. The level of accuracy of the readings of the sensors is influenced by the State of the weather at the location test. Communication on the part of the delivery of data from the results of these tests have a median delay average $1-3$ seconds because each location; different networks and highly influential on your internet connection. Android gui on testing that was done starting from the similarity of data from sensors, perthitungan fuzzy logic and the stability of the gui. From the results of testing the android gui shows the results that correspond to data from sensors and fuzzy logic calculation in accordance with its mathematical calculations. From the analysis of the whole system can work with what you want and endurance test that this tool can work between $1-5$ hours, but tests conducted between $1-4$ hours per day for 5 days testing due to several factors including the following: bad weather and supply used could not last less than 5 hours. It does not affect system performance because of such circumstances as expected at this time. 


\section{CONCLUSION}

The conclusion of the results of the study described in this section:

1. Architecture of tools can work according to the method used, the sensor readings that are used successfully in accordance with the location of sea water in the test. This tool can also communicate with smart phones using the internet and the tools to measure the success of the implemetasi sea water was $97.93 \%$. But in the second trial suffered no stable internet connection and data sent is not stable. There are many factors why the unstable internet connection including weather environment and network connections less maximum.

2. Communication systems working as expected, help with internet connection and the web server then this tool can send parameters from sensors to smart phones via internet connection.

3. Overall this tool can work well in controlling the $\mathrm{pH}$ and salinity of sea water by maintaining the value of salinity between $28-34$ and $\mathrm{pH}$ between 7-8. Fuzzy systems can work as desired.

Advice from research results are described in this section:

1. Could be developed with some of the other supporting factors.

2. Fuzzy methods can be replaced by other methods.

\section{REFERENCES}

[1] http://www.bppp-tegal.com/web/index.php/artikel/98 artikel/artikel-pegaraman/171-memilih-lokasi-tambak-garamrakyat [07-11-2017].

[2] DinaMulyaSiltri,Yohandri,ZulhendriKamus,"Pembuatanalatukur salinitasdan

kekeruhanairmenggunakansensorelektrodadanLDR,"JurnalSainst ek,Vol.VII, No.2,hlm.126-139,2015.

[3] Siti Khodijah, R Rumani M, Unang Sunarya,"Perancangan Dan Implementasi Alat Ukur Untuk Penentuan Kualitas Air Berbasis logika fuzzy Metode Sugeno," e-Proceeding of Engineering, Vol. 4, No. 2, 2017.

[4] Nur Asyiah Agustina, Nirmalasari Idha Wijaya, Viv Djanat Prasita"Kriteria Lahan Untuk Budidaya Rumput Laut (Eucheuma Cottonii) Di Pulau Gili Genting, Madura," Seminar Nasional Kelautan XII, Inovasi Hasil Riset dan Teknologi dalam Rangka Penguatan Kemandirian Pengelolaan Sumber Daya Laut dan Pesisir, Surabaya 2017.

[5] Febriana Tirta, Suryono, "Rancang Bangun Sistem Monitoring Kadar Salinitas Air Menggunakan Wireless Sensor System (WSS)," Youngster Physics Jounal, Vol. 5, No. 4, hlm. 227-234, 2016.

[6] Fahmi Mubarok, Harianto, Madha Christian Wibowo, "Pengendalian Salinitas pada Air Menggunakan Metode Fuzzy Logic," JAVA Journal of Electrical and Electronics Engineeringm, Vol. 13, No. 1, 2015.

[7] Eko Ihsanto, Sadri Hidayat, "Rancang Bangun Sistem Pengukuran Ph Meter Dengan Menggunakan Mikrokontroller Arduino Uno,” Jurnal Teknologi Elektro, Vol. 5, No. 3, 2014.

[8] Agung, M Bangun.2014. Arduino For Beginners. Tugas Akhir Pada Prodi Human Computer Interaction di Universitas Surya. Tanggerang: STKIP Surya.

[9] "USU Institutional Respository (USUIR),'[Online].Available:http:/repository.usu.ac.id/bitstream/1234 56789/43703/4/Chapter\%20II.pdf. [07-11-2017].

[10] Datashet "Sensor Konduktivitas / TDS / Kadar Garam," www.depoinovasi.com [07-11-2017].

[11] T.Tutojo dan Mulyanto, Edy dan Suhartono, Vincent. Kecerdasan Buatan, Andi Offset. Yogyakarta, 2011.

[12] https://id.wikipedia.org/wiki/Air_laut [07-11-2017].

[13] Athena Karumbaya, Gowri Satheesh, "IoT Empowered Real Time Environment Monitoring System"International Journal of
Computer Applications (0975-8887), Volume 129-No.5, November 2015.

[14] Nan Yan, Petra Marschner, Wenhong Cao, Changqing Zuo, Wei Qin, "Influence of salinity and water content on soil microorganisms," Sciencedirect, International Soil and Water Conservation Research 3, p. 316-323, 2015.

[15] J. a. K. S. G. M. Tan, "A Survey of Technologies in Internet of Things. IEEE International Conference on Distributed Computing in Sensor Systems,” p. 269-274, 2014. 